\title{
IMPROVEMENT OF NATIONALISM REFLECTED IN PANCASILA'S 3 rd SILA THROUGH THE ART OF REOG KENDHANG
}

\author{
Andreas Andrie DJATMIKO \\ Prodi Pendidikan Pancasila dan Kewarganegaraan STKIP PGRI Tulungagung \\ Email: lonobydj2@gmail.com
}

\begin{abstract}
Community Service is one of the programs that are needed by the community today. This is done as an effort to respond to the needs of the community and is real program and realistic, especially in the fields of education, social, economic and cultural. Community Service Program is a program that is learning, studying and serving that is realized in the form of introduction and appreciation of community development through the clarity of planned change programs and problem solving methods regarding the ability to choose and use the right skills.

A big nation is a nation that wants to respect its culture. Indonesia has a diversity of cultures that are characteristic and assets of the Indonesian nation. But most of the younger generation has forgotten a lot of the culture of the nation. The tendency of the younger generation now prefers outside cultures and many younger generations are less able to sort out most of which have negative impacts rather than a positive impact on themselves and others as well as the environment. There is a need for character education so that the younger generation can be relied upon in the future according to the nation's culture, such as being responsible for mutual cooperation, mutual assistance and good manners.

Reog Kendhang's art proves that local culture can increase the sense of community nationalism and be able to become social controls so as not to fall into bad lifestyle. The formation of a national culture that can truly reunite all components of the nation's culture, therefore it is necessary to have a deeper introduction to history and cultural heritage in search of the identity of a pluralistic Indonesian society.
\end{abstract}

Kata kunci: increased nationalism, the 3rd precept of Pancasila, reog kendhang art 


\section{PENDAHULUAN}

\section{A. Dasar Pemikiran dan Analisis Situasi}

Melalui berbagai program, salah satunya adalah kegiatan Pengabdian pada Masyarakat, yang mana hal ini dilakukan untuk memenuhi tuntutan Tri Darma Perguruan Tinggi yaitu darma yang ketiga "dharma pengabdian kepada masyarakat" merupakan kegiatan yang berlaku bagi setiap Dosen dan Tenaga Pengajar di STKIP PGRI Tulungagung. Pelaksanaan Kegiatan Pengabdian Kepada Masyarakat ini juga tidak hanya sebatas kewajiban tetapi merupakan lanjutan dari Dharma Perguruan Tinggi sebelumnya yaitu "dharma pengajaran dan penelitian" guna mendewasakan tingkat pemikiran setiap dosen dan tenaga pengajar yang berada di lingkungan STKIP PGRI Tulungagung sehingga kedepanya diharapkan lebih dapat mengembangkan diri dan membantu masyarakat dalam hal positif di tengah-tengah masyarakat serta lingkungan sekitarnya.

Kegiatan Pengabdian Masyarakat adalah salah satu program yang sangat dibutuhkan masyarakat pada saat sekarang ini. Hal ini dilakukan sebagai upaya merespon kebutuhan masyarakat dan bersifat real program serta realistis terutama dalam bidang pendidikan, sosial, ekonomi dan budaya.

Pelaksanaan Kegiatan Pengabdian Masyarakat yang berlokasi di desa-desa merupakan daerah yang telah disurvey sebelumnya oleh beberapa instansi ataupun oleh lembaga-lembaga masyarakat guna memastikan perlu tidaknya daerah tersebut untuk dibina dari segala aspek dengan harapan agar tatanan kehidupan masyarakat menjadi lebih baik dan lebih menghasilkan.

Tumbuh dan perkembangannya kesenian dalam masyarakat seiring pertumbuhan dengan perkembagan sosial budaya masyarakat pendukungnya, sampai sekarang dikenal berbagai macam cabang kesenian di antaranya seni rupa, seni musik, seni tari dan drama Koenjaraningrat, (1993:115). Kesenian Reog Kendhang merupakan kebudayaan yang diwariskan secara turun-temurun untuk generasi muda agar menumbuhkembangkan rasa bangga yang akan melandasi munculnya rasa cinta tanah air, salah satu efek dari modernisasi, remaja sekarang lebih suka dengan hal-hal yang bersifat modern dari pada keseniannya sendiri.

Nasionalisme adalah rasa memiliki, rasa kebanggaan, rasa menghargai, rasa menghormati dan loyalitas yang dimiliki oleh setiap individu pada negara tempat ia tinggal yang tercermin dari perilaku membela tanah airnya, menjaga dan melindungi tanah airnya, rela berkorban demi kepentingan bangsa dan negaranya, mencintai adat atau budaya yang ada dinegaranya dengan melestarikan alam dan lingkungan. Salah satu cara untuk menumbuh kembangkan rasa cinta tanah air adalah dengan menumbuhkan rasa bangga terhadap tanah airnya melalui kesenian. Rasa bangga terhadap tanah air dapat ditumbuhkan dengan memberikan pengetahuan dengan berbagai nilai-nilai budaya yang kita miliki bersama.

Dirasa sangat diperlukan pengembangan nilai-nilai Pancasila dalam kehidupan sosial budaya, salah satu caranya menumbuh kembangkan nilai-nilai Pancasila pada khususya sila ketiga. Nilai yang terkandung dalam sila Persatuan Indonesia tidak dapat dipisahkan dengan keempat sila lainnya karena seluruh sila merupakan suatu kesatuan yang bersifat sistematis. Sila ketiga ini meliputi persatuan dan kesatuan dalam arti idiologis, ekonomi, politik, sosial budaya dan keamanan. Perwujudan Sila ketiga pancasila adalah manifestasi paham kebangsaan yang memberi tempat bagi keberagaman budaya atau etnis yang bukannya ditunjukkan untuk perpecahan namun semakin eratnya persatuan, solidaritas tinggi, serta rasa bangga dan kecintaan kepada bangsa dan kebudayaan. Diharapkan nantinya setelah mengerti dan memahami pentinya penerapan nilai dari pancasila, generasi muda menerapkan sikap cinta tanah air, toleransi, salin menjaga atau melindunggi, rela berkorban demi bangsa dan Negara dengan cara bahu-membahu (gotong-royong). Serta mengenalkan dan memajukan kebudayaan negaranya dalam pergaulan demi persatuan dan kesatuan bangsa yang berbentuk Bhineka Tunggal lka. 


\section{B. Tujuan}

Tujuan Program pengabdian kepada masyarakat dengan judul Peningkatan Nasionalisme Yang Tercermin Dalam Sila Ke-3 Pancasila Melalui Kesenian Reog Kendhang ini adalah:

Untuk meningkatkan rasa nasionalisme yang tercermin dalam sila ke-3 Pancasila melalui kegiatan kesenian yang ada di masyarakat, yakni Kesenian Reog Kendhang

\section{Manfaat}

Sedangkan manfaat program ini adalah sebagai berikut:

1. Bagi Masyarakat daerah kabupaten Tulungagung:

- Memberikan Wawasan baru kepada Masyarakat Tulungagung, bahwasanya Kesenian Reog Kendhang dapat diandalkan menjadi media pemersatu masyarakat, yang juga dapat menumbuhkan rasa nasionalisme sesuai dengan sila ke-3 Pancasila

\section{Bagi Dosen:}

- Dosen dapat melakukan Pengabdian Masyarakat sebagai wujud Tri Dharma perguruan tinggi.

- Meningkatkan kreatifitas inovatif dosen untuk membantu pemerintah dalam menumbuhkan kembali ras nasionalisme yang ada pada masyarakaat daerah, sesuai tujuan yang terkandung dalam Pancasila sila ke-3.

\section{TINJAUAN TEORITIS}

\section{- Kesenian}

Kesenian merupakan salah satu unsur kebudayaan yang sangat dibutuhkan oleh manusia dalam memenuhi kebutuhan hidupnya yang bersifat indah dan diungkapkan melalui gerak maupun sikap seseorang.

Seni adalah karya yang diciptakan dengan keahlian yang luar biasa, seperti tari, lukisan, ukiran Alwi, (2002:1037). Seni adalah hasil ciptaan manusia yang mengandung keindahan. Seni adalah karya manusia yang mengkomunikasikan pengalaman-pengalaman batinnya, dan pengalaman batin tersebut disajikan secara indah atau menarik sehingga merangsang timbulnya pengalaman batin juga kepada manusia lain yang menghayatinya Soedarsono, (1978:5).

Menurut pendapat Kayam, (1981:15) kesenian adalah salah satu unsur yang menyangga kebudayaan. Melalui kesenian manusia dapat berekspresi sesuai dengan apa yang dirasakan. Kesenian merupakan salah satu bagian dari kebudayaan yang sangat dekat dengan kehidupan manusia. Hal itu disebabkan karena kesenian berperan sebagai tempat untuk mengungkapkan ekspresi manusia dengan berbagai media.

Kesenian Reog Kendhang adalah suatu kesenian yang bentuk penyajiannya masih sederhana. Namun, dengan berkembangnya zaman grup Kesenian Reog Kendhang yang ada di daerah Tulungagung berkreasi dengan selalu mengolah dengan segala potensi yang di miliki agar selalu menarik dan lebih dapat diterima khususnya oleh masyarakat.

Kegiatan Pengabdian Kepada Masyarakat ini memfokuskan pembahasan pada Peran Reog Kendhang dalam meningkatkan rasa

nasionlisme dalam aspek bentuk penyajian Kesenian Reog Kendhang di Desa Gandekan Kecamatan Wonodadi kabupaten Blitar peran kesenian tersebut dapat meningkatkan rasa nasionalisme generasi muda sekaligus melestarikan budaya lokal. 


\section{- Reog}

Keberadaan kesenian merupakan salah satu kekayaan seni kerakyatan yang di dalamnya terdapat aspek kreatifitas. Kesenian Reog mengandung nilainilai kebudayaan yang ada pada masyarakat pedesaan sehingga memunculkan kesenian baru dan berkembang ke luar daerah Jawa Timur Kayam, (1981:63).

Kesenian Reog dimata orang berpikir bahwa Kesenian Reog merupakan Kesenian yang terdapat di Ponorogo. Sebenarnya Kesenian Reog tidak hanya di Ponorogo saja tetapi di daerah lain juga ada misalnya di Jawa Timur, Sunda, Gunung Kidul, dan Bantul.

\section{- Sejarah Reog Kendhang}

Menurut Hartono Reyog adalah Reyog berasal dari kata rog yang sama artinya dengan reg berarti erog, herog, horeg. Sedang kata og sama dengan rog menjadi hoyog, eyog. Kesemuanya mengandung arti bergerak atau guncang. Di duga kelahiran kesenian ini pada waktu situasi sedang dalam keadaan tidak tenang Hartono, (1980: 39).

Versi cerita Jathasura dan Ratu Kilisuci yang menggambarkan perarakan Ratu Kilisuci ke Gunung Kelut dan peristiwa "Ratu Kilisuci" jatuh ke dalam sumur lalu di ikuti Jathasura yang kemudian ditimbun dengan batu-batu besar. Para prajurit pulang ke kerajaan bergembira karena keberhasilannya tersebut, itulah tema yang diungkapkan ke dalam pertunjukan Reyog Gemblug.

Kata "Reyog" diambil dari kata-kata Jawa yaitu "riyet" dan "reyot". Kata-kata ini mempunyai arti yang menggambarkan kelelahan dan kesulitan perjalanan prajurit perarakan Ratu Kilisuci tersebut Soenarto Timoer, (1978/79: 62-69).

\section{- Nasionalisme}

Sastroatmodjo (1994:7) mengemukan yaitu: Bagi bangsa Indonesia, nasionalisme merupakan hal yang sangat mendasar, sebab ia telah membimbing dan menghantar bangsa Indonesia dalam mengarungi hidup dan kehidupannya. Ini berarti bahwa nasionalisme itu akan selalu terkait dengan perjalanan sejarah bangsa Indonesia. Dengan demikian nasionalisme itu baru akan dapat dipahami secara jelas jika dikaitkan dengan ideologi nasionalnya. Ini berarti melihat nasionalisme itu dari perspektif pancasila.

Pancasila sebagai ideologi adalah wahana untuk memahami cita-cita berikut sifat-sifatnya dan sumbernya. Menurut Greenfeld dan Chirot (dalam Susiatik 2007:15): Nasionalisme adalah seperangkat gagasan dan sentimen yang membentuk kerangka konseptual tentang identitas nasional yang sering hadir bersama dengang berbagai identitas lainnya seperti okupasi, agama, suku, ligistik, territorial, kelas, gender, dan lainlain. Mengamati beberapa pendapat dari para ahli di atas tentangnasionalisme, maka yang tidak kalah penting untuk dibahas pula adalah tentang kalsifikasi nasionalisme. Nasionalisme terbagi menjadi beberapa bagian.

Nasionalisme dalam pandangan Carlton diklasifikasikan ke dalam (lima) jenis yaitu:

a. Nasionalisme humaniter, yang bersifat toleran yang mendasar pandangannya bahwa setiap bangsa berhak memperjuangkan kesejahteraan bangsanya berdasarkan caranya sendiri.

b. Nasionalisme yacobin, yang demokratis tetapi doktriner dan fanatik terhadap bangsa lain.

c. Nasionalisme tradisional, yang menekankan keunikan setiap bangsa dan mempertahankan tradisi yang dan sejarahnya.

d. Nasionalisme liberal, yang menekankan pentinngnya dalam perwakilan dari gagasan perlunya dunia berpegang pada prinsip setiap bangsa berhak menentukan nasibnya sendiri.

e. Nasional integral, yang menekankan kepentingan nasional ada diatas kepentingan individu, maka individu harus sepenuhnya setia kepada Negara Sneyder Louis dalam Susiatik (2007:16). 


\section{- Menumbuhkan Nasionalisme Melalui Nilai Yang Terkandung Dalam Pancasila}

Sebagai dasar negara, Pancasila adalah barometer moral di mana kerangka kewarganegaraan harus didasarkan. Pancasila secara fundamental merupakan kerangka yang kuat untuk pendefinisian konsep kewarganegaraan yang inklusif, sebab didalamnya memiliki komitmen yang kuat terhadap pluralisme dan toleransi. Komitmen inilah yang mampu mempersatukan dan menjaga keutuhan bangsa yang terdiri 400 lebih kelompok etnis dan bahasa.

Inilah pentingnya kita kembali peduli kepada Pancasila, melaksanakan komitmen-komitmennya dan menegakkan prinsip-prinsip kewarganegaraan. Sebagai warga negara, kita juga memiliki tanggung jawab mengawasi pelaksanaan komitmen-komitmen tersebut, agar tidak melenceng dari garisnya.

Sebenarnya banyak cara menumbuh kembangkan rasa nasionalisme masyarakat Indonesia ditengah wacana mengenai kekhawatiran akan semakin tajamnya kemerosotan nasionalisme. Nasionalisme dapat dipupuk kembali dalam momentum-momentum yang tepat seperti pada saat peringatan hari sumpah pemuda, hari kemerdekaan, hari pahlawan dan hari besar nasional lainnya, guru maupun dosen yang tulus mengajar dengan baik dan dengan ikhlas menuntun para siswa hingga mampu mengukir prestasi yang gemilang, pelajar yang belajar dengan sungguh-sungguh dengan segenap kemampuannya demi nama baik bangsa dan Negara, cinta serta bangga tanpa malu-malu menggunakan produkproduk dalam negeri demi kemajuan ekonomi Negara. Bukan itu saja nasionalisme juga dapat dibangun melalui karya seni seperti menciptakan lagulagu yang berslogan cinta tanah air, melukis, seni peran yang bertajuk semangat juang untuk Negara dan karya-karya seni lainnya. Menumbuhkan semangat nasionalisme yang tangguh, missal semangat mencintai produk dalam negeri.

Menanamkan dan mengamalkan nilai-nilai Pancasila dengan sebaik-baiknya. Menanamkan dan melaksanakan ajaran agama dengan sebaik-baiknya. Mewujudkan supremasi hukum, menerapkan dan menegakkan hukum dalam arti sebenar-benarnya dan seadil-adilnya. Selektif terhadap pengaruh globalisasi di bidang politik, ideologi, ekonomi, sosial budaya bangsa. Oleh sebab itu, bangsa Indonesia harus mempunyai akar-budaya dan mengikat diri dengan nilai-nilai agama, adat istiadat, serta tradisi yang tumbuh dalam masyarakat.

Pancasila dapat ditetapkan sebagai dasar negara karena sistem nilainya mengakomodasi semua pandangan hidup dunia internasional tanpa mengorbankan kepribadian Indonesia. Hal ini akan menjaga nilainilai luhur bangsa dan semangat untuk ber-nasionalisme. Nasionalisme bangsa Indonesia dapat terus dipertahankan dan dilestarikan dengan mengimplementasikan seluruh nilai-nilai Pancasila dalam keseluruhan kehidupan berbangsa dan bernegara. Yang sesuai dengan pengamalan nilai-nilai Pancasila pada sila ke-3 yakni Persatuan Indonesia yang bermakna Menjaga Persatuan dan Kesatuan Negara Kesatuan Republik Indonesia.

\section{- Implementasi Nilai-Nilai Pancasila}

Implementasi Pancasila adalah operasionalisasi nilai-nilai yang terkandung di dalam Pancasila tentang bagaimana, mencakup apa saja dan siapa saja penerapan nilai-nilai itu diwujudkan. Implementasi nilai-nilai Pancasila menjadi suatu keharusan yang wajib dilakukan oleh siapa saja yang menjadi warga negara Indonesia.Isi nilai-nilai yang terkandung di dalam setiap pasal Pancasila yang bersifat abstrak, umum universal bukan hanya sebagai angan-angan belaka, tetapi mempunyai peranan yang penting dalam pelaksanaan dasar filsafat negara Indonesia yaitu sebagai suatu inti pedoman dasar yang tetap.

Pancasila sebagai dasar filsafat Negara Indonesia mengandung konsekuensi setiap aspek penyelenggaraan negara dan semua sikap dan tingkah laku bangsa Indonesia dalam bermasyarakat dan bernegara harus berdasarkan pada nilai-nilai Pancasila. Sebagaimana telah dibahas di muka bahwa nilai-nilai Pancasila yang bersumber pada hakikat Pancasila adalah bersifat abstrak, umum universal, tetap dan tidak 
berubah. Nilainilai tersebut perlu dijabarkan lebih lanjut menjadi norma-norma kenegaraan maupun normanorma moral yang harus dilaksanakan oleh setiap warga negara Indonesia Kaelan, (2002:240).

Pancasila sebagai dasar filsafat negara Indonesia oleh karena itu antara warga dan negara harus mempunyai hubungan yang adil yaitu antara hak dan kewajiban. Negara mempunyai wajib distributive yaitu wajib diberikan kepada warga negara segala sesuatu yang menjadi haknya. Sebaliknya warga negara wajib taat kepada negara sebanyak hak hidup negara. Tanpa ketaatan warga negara tidak ada negara yang dapat berlangsung Daroeso, (1989:81).

\section{HASIL PELAKSANAAN KEGIATAN}

\section{Hasil Kegiatan}

Implementasi Nilai-Nilai Sila 3 Pancasila dalam meningkatkan rasa nasionalisme melalui Kesenian Reog Kendhang satriyo mudo dalam kegiatan latihan rutin maupun kegiatang pentas seni sepertinya tidak sulit dilakukan oleh pelaku kesenian maupun penikmat kesenian atau masyarakat pada umumnya. Nilai-nilai Pancasila sesungguhnya merupakan nilai-nilai yang sesuai dengan hati nurani bangsa Indonesia, karena bersumber pada kepribadian bangsa. Nasionalisme Indonesia secara umum bertujuan kedalam memperhebat nation building dan character building sesuai dengan falsafah dan pandangan hidup bangsa.

Pelaksanaan kegiatan kesenian reog kendhang merupakan bentuk dari implemtasi nilai-nilai pancasila yang di pupuk oleh masyarakat agar rasa nasionalisme dalam setiap individu maupun seluruh golongan dapat memper erat persatuan dan saling menjaga dari segala aspek permasalahan yang terdapat dalam kehidupan bermasyrakat desa gandekan. Dalam Kegiatan kesenian reog kendhang terdapatnya pesan-pesan pada Kisah Sejarah Reog Kendhang dan setiap makna Simbolis Busana Penari Reog Kendhang dapat dijadiakan sebagai pesan moral pada lingkungan sosial masyarakat desa gandekan, dari hal tersebut baik dari pelaku kesenian dan masyarkat pada umumnya mengabil pesan terdapat dari simbul busana penari maupun tarian reog kendang untuk dihayati serta di amalkan yang didasari pada nilai-nilai yang terdapat dalam Pancasila.

\section{Sejarah reog kendhang}

Nilai legenda atau cerita dapat dilihat dari asal-usul kesenian ini yang berawal dari sebuah cerita atau legenda. Dewi Kilisuci merupakan putri ketiga dari kerajaan Kediri. Dewi Kilisuci merupakan putri yang cantik jelita namun memilih menjadi Pendeta karena sudah bosan dengan hal-hal yang bersifat duniawi. Banyak raja-raja di Nusantara yang ingin melamar Dewi Kilisuci, namun Dewi Kilisuci menolak semua lamaran dari raja-raja tersebut. Raja-raja itu pun tidak ada lagi yang memaksakan kehendaknya dikarenakan mereka kalah sakti dibandingkan dengan Dewi Kilisuci.

Pada suatu ketika ada raja dari kerajaan Bugis yang melamar Dewi Kilisuci. Dewi Kilisuci akhirnya menerima lamaran Raja Bugis tersebut dan menyerah karena raja Bugis sangat kuat. Tetapi Dewi Kilisuci tidak mau menerima begitu saja lamarannya, ia meminta bebono atau syarat yang harus dipenuhi oleh Raja Bugis jika ingin menikahi Dewi Kilisuci. Raja Bugis pun bersedia untuk memenuhi persyaratan-persyaratan yang diberikan oleh Dewi Kilisuci. Syarat yang diutarakan oleh Dewi Kilisuci juga menunjukkan kiasan yang berarti Dewi Kilisuci menolak lamaran Raja Bugis secara halus. Para prajurit merasa kebingungan. Pada saat itu juga para prajurit datang ke desa Dadhap Langu, Tulungagung untuk meminta bantuan kepada warga di desa tersebut untuk mengartikan kiasan tersebut sekaligus untuk membuatkannya. Setelah bertemu dengan warga desa akhirnya mereka membantu para prajurit.Syarat yang dimaksud mempunyai arti yaitu:

a. Mata ayam tukung lebarnya sebesar terbang miring diartikan Gong dan Kempul, sedangkan digantung di gubuk penceng dapat diartikan Gayor.

b. Seruling Pohon padi sebesar batang pohon kelapa diartikan Slompret.

c. Dendeng tumo sak tetelan pulut (alat untuk menumbuk jadah) diartikan Kenong. 
d. Ati tengu sebesar bantal (guling) diartikan Iker.

e. Madu lanceng 6 (enam) bumbung diartikan Dhodhog (bumbung) atau Kendhang yang berjumlah enam buah.

f. Binggel emas yang bisa berbunyi sendiri diartikan Gongseng Setelah prajurit Bugis berhasil mendapatkan bebono yang disyaratkan Dewi Kilisuci akhirnya mereka menemui Dewi Kilisuci dengan membentuk sebuah formasi barisan, dari formasi inilah maka terciptalah gerak baris.

Sebelum diserahkan ke Dewi Kilisuci para prajurit memohon ke Sang Pencipta dengan memandang ke bawah dan ke atas lalu kekanan, dan ke kiri. Gerakan inilah yang disebut dengan gerak bumi langit atau Sundangan. Setelah itu para prajurit semedi dengan cara menggeduk tanah supaya barang-barang bebono tersebut diterima. Gerak dengan cara menggeduk tanah ini dinamakan gerakan Gejoh Bumi.

Setelah selesai melakukan semedi para prajurit mulai berjalan mengantarkan barang bebono tersebut dengan berjalan seperti hewan menthog. Gerakan ini disebut dengan gerakan Menthokan. Setelah barangbarang itu diserahkan para prajurit mundur/lengser. Dari gerakan mundur ini maka terciptalah gerak Patetan. Dewi Kilisuci memeriksa bebono tersebut dengan disaksikan para prajurit yang melingkar, dari gerakan melingkar ini tercipta gerak Lilingan. Setelah Dewi Kilisuci merasa cocok dengan barang-barang tersebut para prajurit merasa kaget dan melakukan gerak melihat ke kanan dan kiri, dari inilah tercipta gerak Midak Kecik. Rasa senang dari prajurit-prajurit tersebut semakin bertambah lalu tanpa meraka sadari Dewi Klisuci menciptakan sesosok tubuh yang mirip dengan dia lalu jatuh masuk ke dalam sumur. Prajurit-prajurit itu langsung kaget lalu melihat ke dalam sumur. Cara melihat ke dalam sumur ini disebut dengan gerakan Ngongak Sumur. Karena sumur itu sangat dalam maka mereka melakukan gerakan yang disebut dengan gerak Kejang Jinjit. Karena Dewi Kilisuci tidak muncul ke permukaan dan hilang maka prajurit mundur dan berbalik.

Gerakan mundur dan berbalik ini disebut dengan gerakan Gembyangan. Para prajurit merasa tidak berhasil memboyong Dewi Kilisuci ke kerajaan Bugis lalu mereka pulang dengan tangan hampa, lalu mereka membentuk gerak Baris lagi.

Kebudayaan pada dasarnya merupakan segala macam bentuk gejala kemanusiaan, baik yang mengacu pada sikap, konsepsi, ideologi, perilaku, kebiasaan, karya kreatif dan sebagainya. Sejarah reog kendhang sebagai sarana untuk dapat mengambil kemanfaatan dari kisah tersebut mulai dari yang negatif dan positifnya untuk dapat di jadikan sebagai barometer dalam kehidupan karena terdapatnya pesan siakap dan pemikiran yang positif harus di miliki (sepert kerja keras, kejujuran, loyalitas, tidak mudah mudah menyerah amanah, menepati janji, dan lain sebagainya), pesan sikap dan pemikiran yang negatif harus tidak dilakukan( seperti( tidak jujur, tidak menepati janji, menipu, dan sebagainya).

\section{Pembahasan Hasil Makna simbolis Busana Penari Reog Tulungagung.}

\section{a) Pakaian pada bagian kepala}

1. Pakaian pada bagian kepala Iket/Udheng, Iket (ikat/ikatan): tali persatuan, Warna hitam: ketenangan, adil, tegas, dan berwibawa, Motif gadhung mlathi: Mlathi/bunga melati dianggap mengandung kesusila an atau rasa susila. Pemakaian motif ini berharap agar mereka dapat hidup makmur baik lahir maupun batin.

2. Iker-iker/gulingan: Salah satu syarat pinangan yang diajukan Kilisuci kepada Jathasura dalam kiasan "ati tengu sebesar guling" kemudian diwujudkan sebagai iker-iker/gulingan. Guling (golong/gumolong): Bersatu, Merah (berani): Berani dalam kebenaran, Putih (suci): Perjuangayang suci/jujur, Jatayu (burung garuda): Lambang kekokohan.

3. Sumping: Sumping dipakai ditelinga yang berarti mendengarkan. Sumping mewakili ciri kepemimpinan Jawa yang selalu menampung aspirasi masyarakat. 


\section{b) Pakaian Tubuh}

1. Kace: bulan sabit dianggap mewakili sikap yang jelas dan lugas.

2. Ter: Diartikan sebagai identitas kepangkatan prajurit, kita dapat melihat pangkat, jabatan, dan tugas yang diemban seorang prajurit dari tanda yang ada pada ter.

3. Baju: Warna putih melambangkan kesucian hati dan sikap seorang prajurit dalam mengemban tugas negara.

4. Srempang: Lambing jati diri seseorang. Bisa dilihat dari bentuk, hiasan, maupun tanda dan tulisan yang tertera pada srempang.

5. Gendhong/gendhongan: diartikan seorang prajurit yang membawa tanggungjawab dimedan perang.

6. Klat Bahu: Kelengkapan busana yang menunjukkan jati diri seorang prajurit.

7. Deker: Menunjukkan jati diri seorang prajurit. Melingkar dipergelangan tangan melambangkan kekuatan dan tekat yang utuh.

8. Stagen: mengikat kuat celana, kain panjang sampur, dan boro-boro menjadi satu dibagian perut. Melambangkan keprihatinan dan tirakat seorang prajurit menahan hawa nafsu dan menyatukan tekat dalam tugas.

9. Sabuk/Timang: sabuk atau ikat pinggang merupakan lambang tali persaudaraan.

10.Keris: Menunjukkan sebuah harapan dan tekad manusia untuk kuat dan teguh dalam menjalankan kehidupan dalam upaya bersatu kembali dengan Tuhan. Keris juga melambangkan kejantanan, sifat keberanian, kebenaran, dan konsentrasi.

11.Kain Panjang: Parang berasal dari kata pareng yang berarti lereng. Menggambarkan garis menurun dari tinggi kerendah secara diagonal. Susunan motif leter $S$ tidak terputus melambangkan kesinambungan. Bentuk leter $S$ diambil dari ombak samudra yang menggambarkan semangat tidak pernah padam. Pemakaiannya dalam Reog Tulungagung, melambangkan sifat kejujuran yang menjadi ciri khas budaya Jawa.

12.Celana/Kathok Makna: Dalam Reog Tulungagung celono berarti pandai-pandai menyimpan rahasia.

13.Boro-boro Makna: Perhiasan/atribut yang menjadi ciri khas busana penari tradisional Jawa.

\section{c) Pakaian Kaki}

1. Kaos kaki Makna: Warna putih dibagian kaki melambangkan langkah kaki yang suci, jujur dan fokus pada satu tujuan. Tidak menggunakan sepatu/ sandal berarti bersahaja dan menyentuh bumi yang dapat diartikan mengerti andap asor/ sopan santun dan tidak sombong.

2. Gongseng: Lonceng melambangkan kekompakan dan kemeriahan, bunyi yang ditimbulkan menyelaraskan ritme langkah dan gerakan para penari Reog Tulungagung.

\section{d) Perlengkapan Tari/ property}

1. Dhodhog/Kendhang: penggambaran madu lanceng dalam bumbung bambu berukuran besar, yang menjadi salah satu seserahan dalam lamaran Jathasura terhadapKilisuci.

2. Sampur: kata sampur berasal dari bahasa Jawa sampurno yang melambangkan kesempurnaan. 
Makna Busana Penari Reog Tulungagung memiliki makna yang mendalam. Yang mencerminkan selayaknya Sebagai individu, manusia hendaknya memiliki sikap dan sifat yang terpuji. Niat hati yang suci, berpendirian kuat, jujur dalam ucapan dan perbuatan. Sebagai masyarakat/rakyat/makhluk sosial, kesusilaan mempunyai kedudukan yang sangat penting dalam kehidupan bermasyarakat, menjaga tali persaudaraan, saling menghormati dengan tujuan hidup makmur lahir dan batin. Bersaing dengan sehat, tidak saling menjatuhkan dengan menjaga rahasia dan kehormatan masing-masing. Sebagai pemimpin harus memiliki jati diri yang kokoh dan tangguh, Bersifat tenang, adil, tegas, lugas, dan berwibawa, Berani menegakkan kebenaran, senantiasa mendengarkan aspirasi rakyat, dan mengutamakan kepentingan rakyat.

\section{e) Penerapan Nilai-nilai Sila ke 3 Pancasila dalam Kesenian Reog Kendhang untuk meningkat rasa nasionalisme}

Bentuk penanaman nilai-nilai kreatif Sila ke 3 Pancasila dalam Kesenian Reog Kendhang untuk meningkat rasa nasionalisme. Pesan yang terdapat dalam kisah sejarah reog kendhang yang memiliki hikmah dan pesan positif yang dapat kita ambil sebagai motivasi dan mengabil kemanfaat yang terdapat dalam sejarah reog kendhang. Hal ini tidak terlepas dari penenanaman pendidikan karakter, karakter adalah berbagai ciri khas dari individu yang menjadi tanda atau identitas yang bersangkutan sehingga membedakan dengan individu yang lain. Pendidikan karakter merupakan landasan dari kesadaran budaya, kecerdasan budaya dan merupakan pula perekat budaya.

Nilai-nilai karakter dalam kegiatan reog kendhang meliputi disiplin, kekeluargaan, bersahabat, peduli sosial, kerjasama, kerjakeras, jujur, rasa toleransi, mandiri, tanggung jawab, rasa ingin tahu, kreatif, nasionalisme atau mencintai kebudayaan. Kelompok kesenian reog kendhang di desa gandekan kecamatan wonondadi kabupaten blitar mempunyai cara untuk ikut berpartisipasi dalam menjaga dan melestarikan kebudayaan, menyampaikan agar nilai-nilai pancasial utamanyan sila ke-3 yang terkandung dalam kesenian reog kendhang dapat menjadi kontrol sosial dan mampu memotivasi untuk bertindak lebih baik lagi bagi para pelaku kesenian reog kendhang, orang tua wali, guru, pemerintah tingkat desa maupun pusat dan penikmat kesenian pada umumnya.

Busana reog kendhang yang memiliki makna mengispirasi untuk berubah menjadi individu atau masyarakat sosial yang lebih baik, ikut berpartisipasi dalam menjaga dan melestarikan kebudayaan, mengamalkan nilai-nilai Pancasila, bangga menjadi orang Indonesia, memahami sejarah kebudayaan, belajar dengan sungguh-sungguh, saling menghargai kebudayaan yang lain. Untuk mengaplikasikannya yaitu dengan terus memotivasi untuk terus belajar melatih gerakan dengan baik, sungguh-sungguh, selalu berjuang, kerja keras, yakin pada diri sendiri, tidak putus asa, tidak ragu-ragu melakukan sesuatu, saling toleransi dan saling membantu antar teman/anggota.

Kesenian reog kendhang dapat membudidaya di desa gandekan, karena pada umumnya, masyarakat ikut berpartisipasi dalam menjaga dan melestarikan kebudayaan, mengamalkan nilai-nialai pancasiala, bangga menjadi orang Indonesia/merasa bangga memiliki budaya bangsa, memahami sejarah kebudayaan yang dapat memper erat sialhrurahim dan persatuan masyarakat desa setempat. 


\section{KESIMPULAN}

Berdasarkan hasil kegiatan pengabdian kepada masyarakat yang telah dilakukan, maka dapat disimpulkan bahwa Peran Kesenian Reog Kendhang Dalam Meningkatkan Rasa Nasionalisme Sebagai Cermin Nilai-Nilai Yang Terkandung Dalam Sila Ke-3 Pancasila di komunitas desa Gandekan. membuktikan bahwasannya budaya lokal mampu meningkatkan rasa nasionalisme masyarakat (motivasi) dan mampu menjadi kontrol sosial agar tidak terjerumus pada gaya hidup yang kurang baik. Kebudayaan Nasional dapat menyatukan kembali seluruh komponen masyarakat, oleh karena itu sangat diperlukan pengenalan lebih dalam lagi tentang sejarah dan warisan-warisan budaya demi mencari jati diri masyarakat Indonesia yang plural.

\section{SARAN DAN REKOMENDASI}

1. Terselenggaranya pelatihan Kesenian Reog Kendhang sebagai salah satu bentuk pelestarian budaya bangsa yang memiliki ciri-ciri khusus terhadap keterikatannya dengan nilai, norma dan kaidah-kaidah yang berlaku di daerah kehidupan dan perkembangannya, khusunya dalam mengimplementasikan nilai-nilai yang tertanam dalam Pancasila.

2. Peran Kesenian Reog Kendhang ini mempunyai efektivitas dan efisiensi yang tinggi karena memiliki tiga aspek materi yaitu pengetahuan (cognitive), perasaan (feeling) dan tindakan (action). Bentuk karakter bangsa yang dapat diperoleh melalui Kesenian Reog Kendhang antara lain: rasa cinta budaya sendiri, memiliki kemampuan (skill), kemampuan estetis, berkepribadian luhur, memiliki kehalusan budi, kebersamaan dan yang paling penting adalah rasa nasionalisme yang tinggi. 


\section{DAFTAR PUSTAKA}

Djam'an Satori, 2011, Metode Penelitian Kualitatif, Bandung, Alfabeta.

Djatmiko, Andreas Andrie.2016. implementasi pendidikan karakter dalam membentuk identitas bangsa multikultar. Tulungagung. Jurnal Rontal Keilmuan PPKn Volume 2

Koentjaraningrat. 1993. Kebudayaan, Mentaitas, dan Pembangunan. Jakarta: PT.Gramedia Pustaka Utama

Rukiyati, Purwastuti, L.A., Dwikurniani,D., et al. 2013. Pendidikan Pancasila. Yogyakarta: UNY Press

Soedarsono, R.M. Diktat Pengantar Pengetahuan dan Komposisi Tari. Yogyakarta: Akademi Seni Tari Indonesia, 1978.

Soegito, Ari Tri. Suprayogi. Rachman, Maman. Pramono, Suwito Eko. Suyatmo. 2006. Pendidikan Pancasila. Semarang: UNNES Press.

Soekanto, Soerjono. 2012. Sosiologi Suatu Pengantar. Jakarta: PT Raja Grafindo Persada

Utomo, Budi Cahyo.1995. Dinamika Pergerakan Kebangsaan Indonesia, dari Kebangkitan

HinggaKemerdekaan. Semarang;IKIP Semarang press 


\section{LAMPIRAN PELAKSANAAN KEGIATAN}

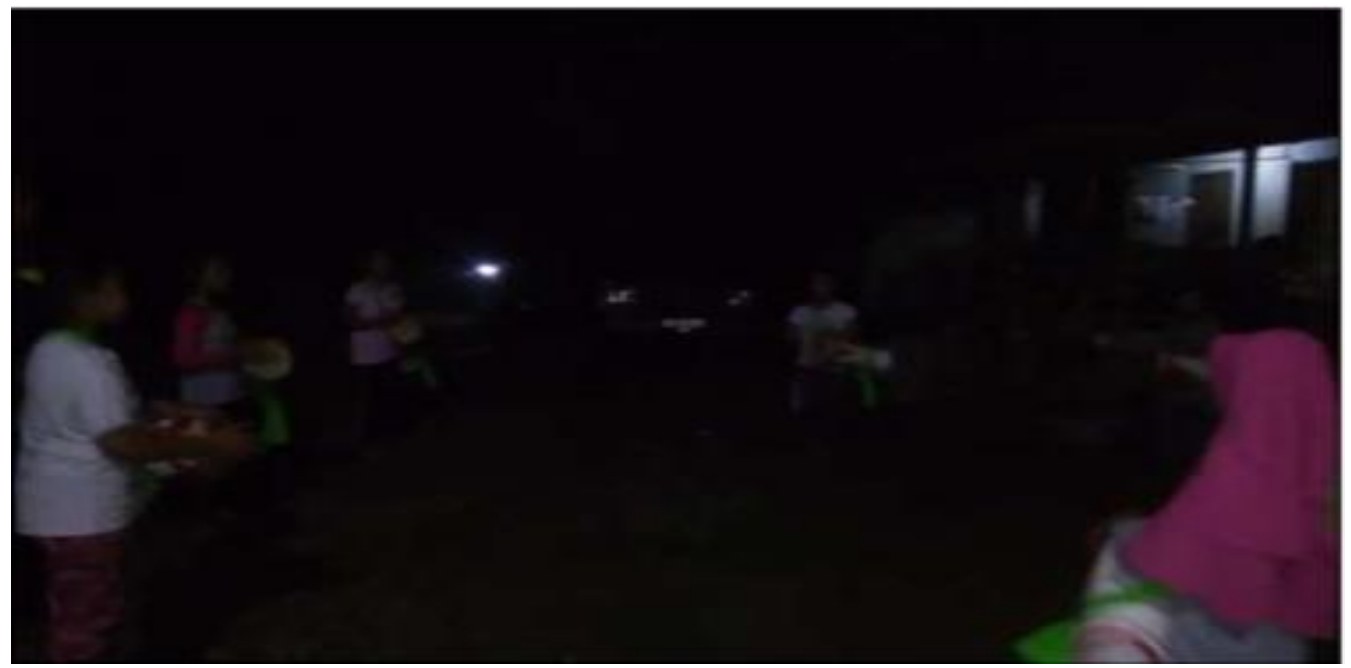

Latihan komunitas Reog Kendhang
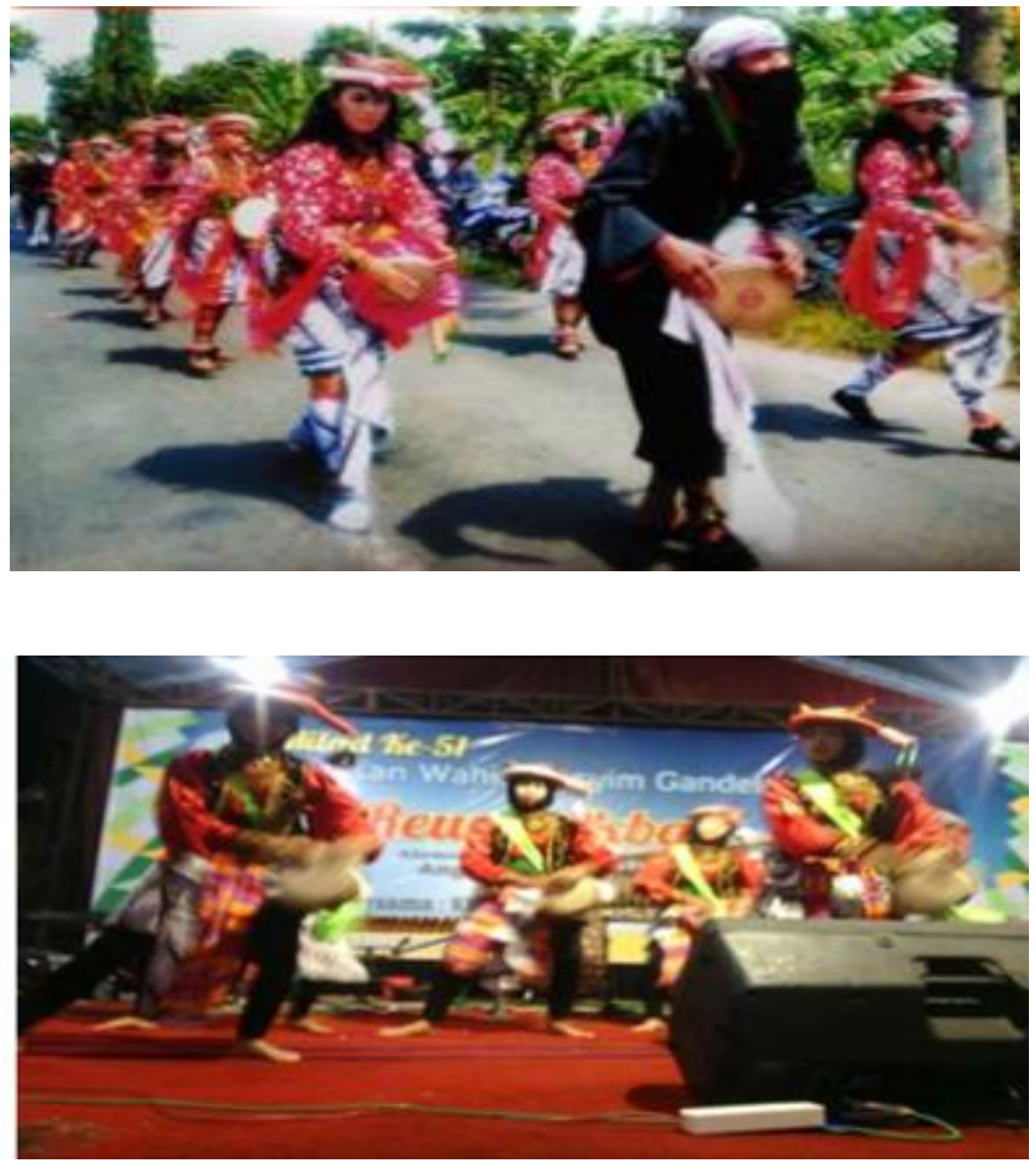

Wujud Kesenian Reog Kendhang 


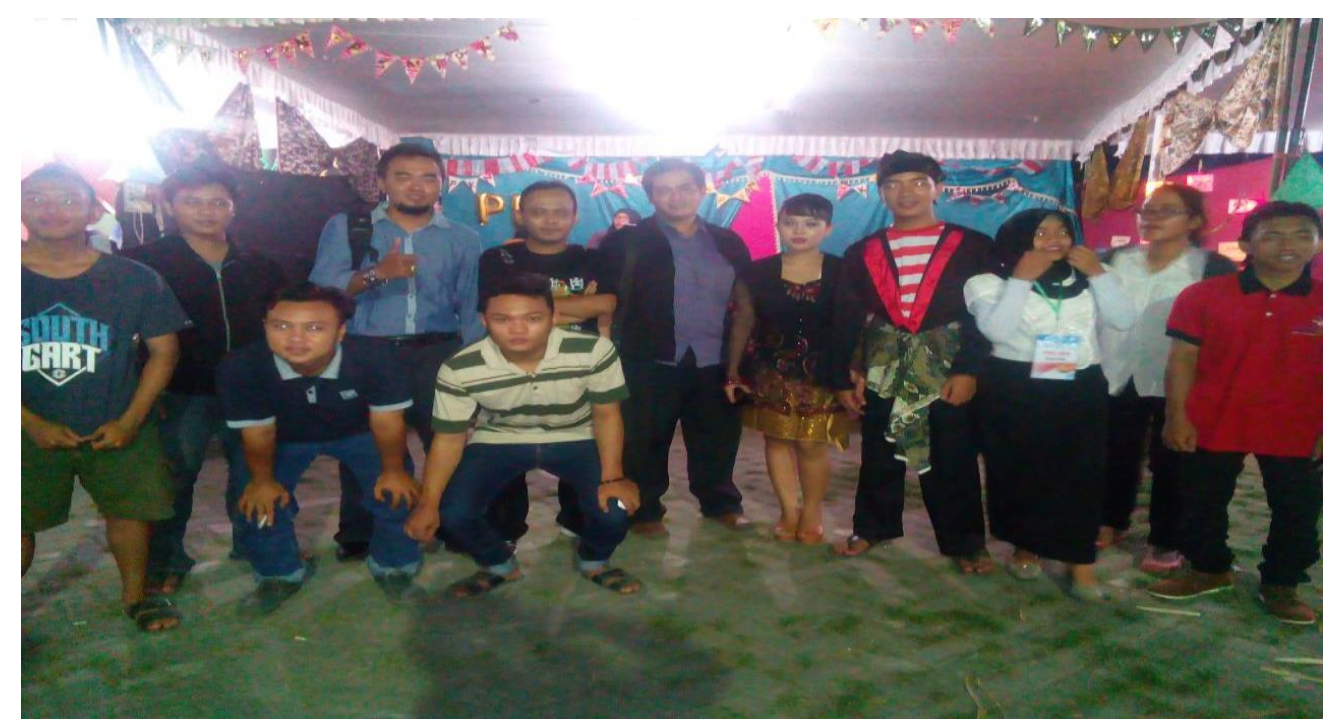

Bersama Pemuda penggiat kesenian Reog Kendhang

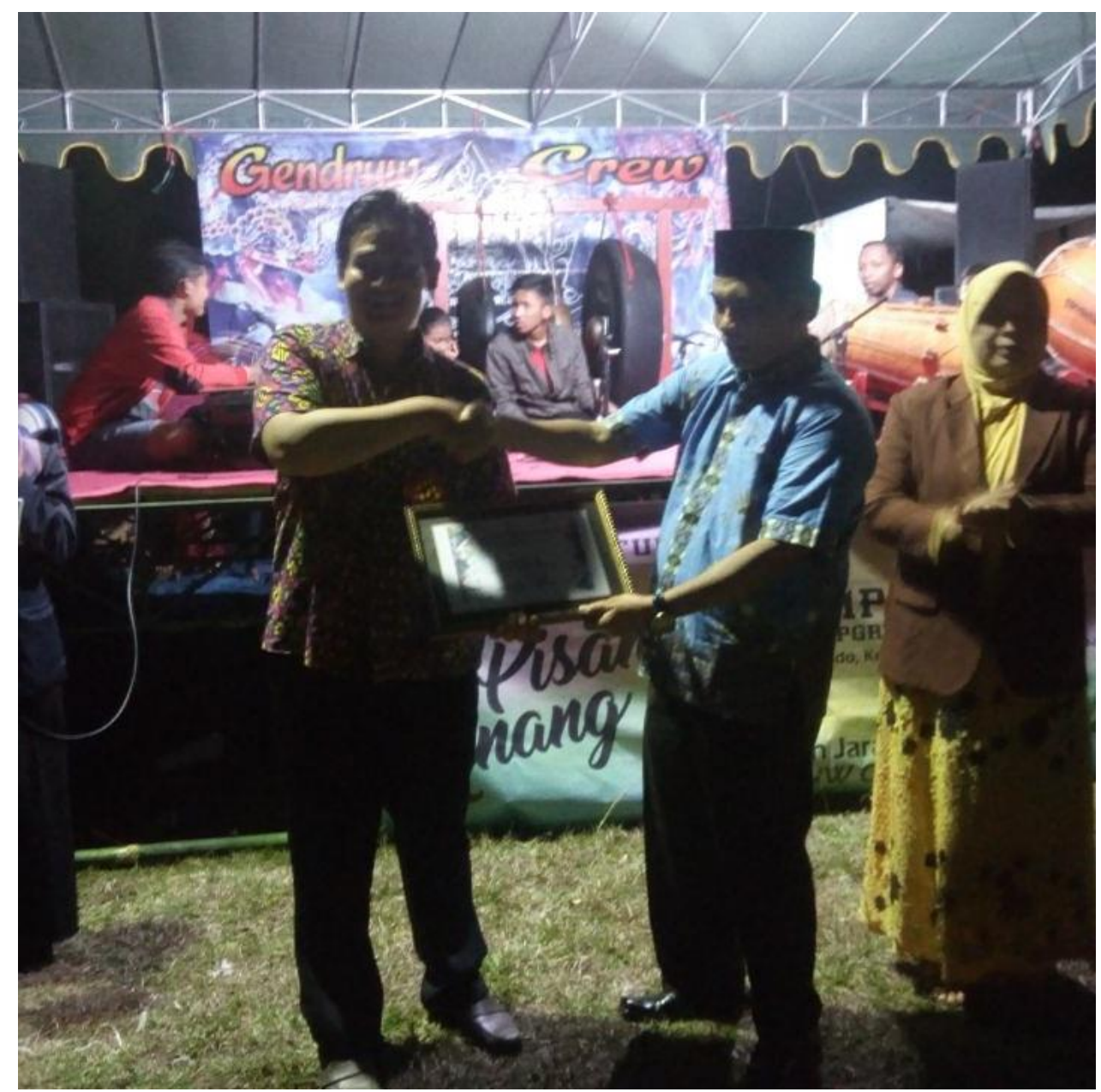

Bersama Pengurus Kesenian Reog Kendhang 


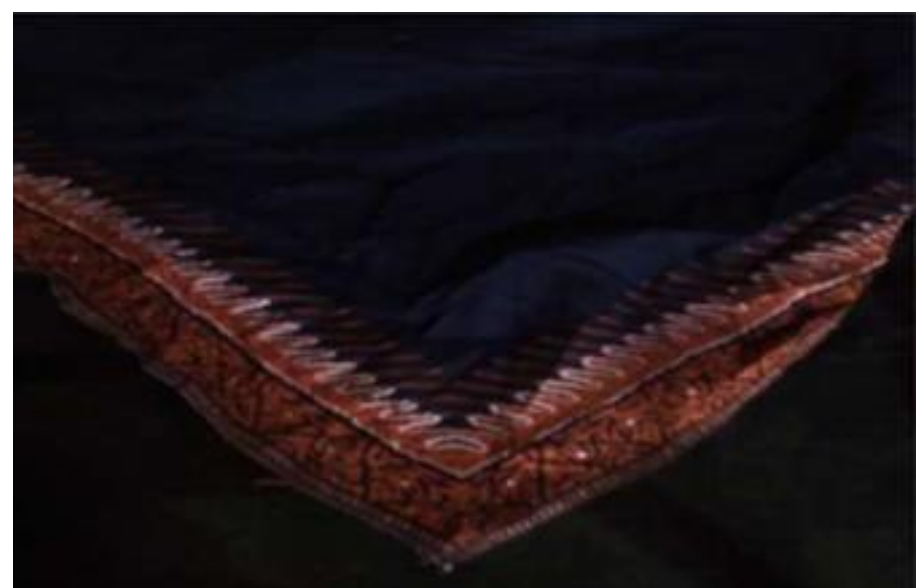

Busana Kesenian Reog Kendhang

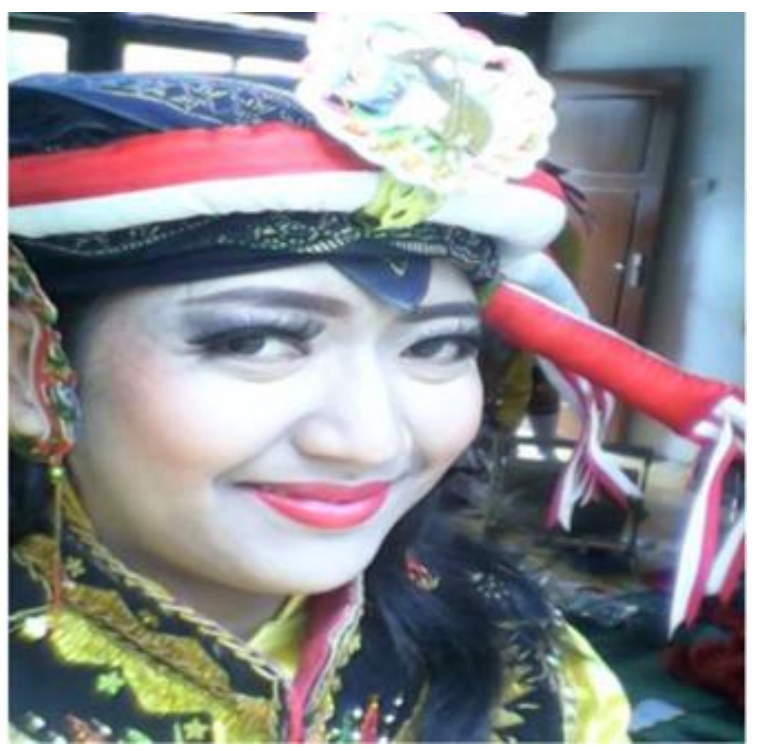

Ikat Kepala/Udheng

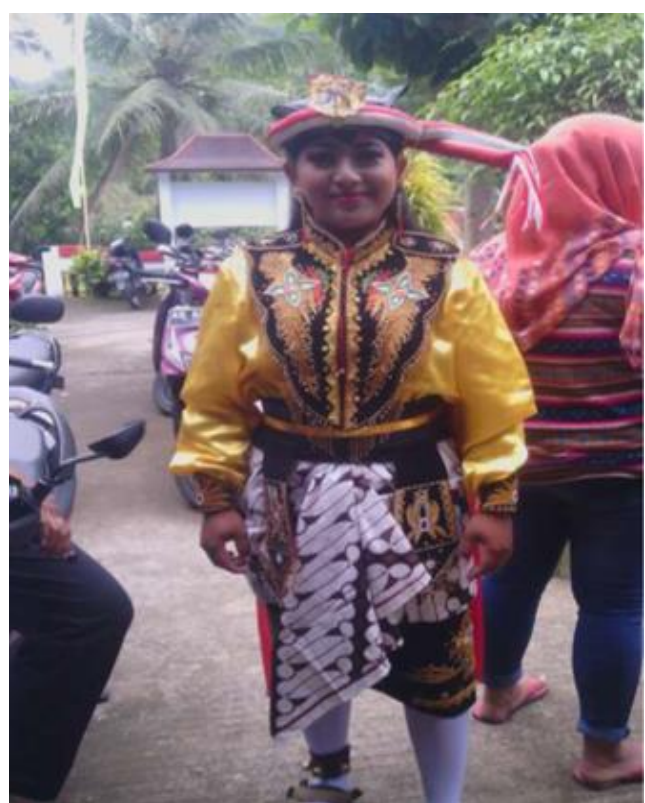

Iker-Iker Dan Sumping \& Busana Lengkap Kesenian Reog Kendhang 